\title{
Spindle Cell Lipoma Occurring
} in the Submandibular Space: Fifth Case
Reported along with a Concise Review
of the Literature

\author{
Manveen Kaur Jawanda ${ }^{1}$, Harshaminder Kaur Grewal ${ }^{2}$, Sonia Gupta ${ }^{3, *}$, Vineet Sharma ${ }^{4}$, Ravi Narula ${ }^{5}$
}

\begin{abstract}
Spindle cell lipoma (SCL) is an uncommon histological variant of lipoma that accounts for $1.5 \%$ of all adipose tumors. It rarely occurs in the oral cavity. The most common sites of involvement are the buccal mucosa, tongue, lip, alveolar mucosa, gingiva, and palate. Submandibular space is a very rare site of occurrence for SCL. When occurs in this site, SCL mainly involves the 4th-7th decade with a female predominance. Due to wide communications of submandibular space, the actual extent and appearance of the lesions present here gets masked up especially those involving the deeper tissues leading to an inaccurate diagnosis. Wide overlap of clinical and histopathological features of SCL to other clinical pathologies leads to a challenging task for the clinicians to reach an accurate diagnosis. To our knowledge, only four cases of intraoral SCL involving the submandibular region directly or indirectly have been reported in the literature. Here we represent another rare case of SCL in an 18-year-old male patient along with a concise review of the literature. This case appears to be quite rare due to its location (submandibular space), age, and sex of the patient (18/M).
\end{abstract}

\section{KEYWORDS}

diagnostic challenge; intraoral; lipoma; spindle cell; submandibular space

\section{AUTHOR AFFILIATIONS}

${ }^{1}$ Dept. of Oral Pathology and Microbiology \& Forensic odontology. Laxmi bai institute of dental sciences and hospital, Patiala, Punjab, India

${ }^{2}$ Waryam Singh Hospital, Yamunanagar, Haryana, India

${ }^{3}$ Dept. of Oral Pathology and Microbiology \& Forensic odontology, Rayat Bahra Dental college and hospital, Mohali, Punjab, India

${ }^{4}$ Dept. of Conservative Dentistry, Laxmi bai institute of dental sciences and hospital, Patiala, Punjab, India

${ }^{5}$ Dept. of Oral and Maxillofacial surgery, Guru Nanak Dev Dental College and Research Institute, Sunam, Punjab, India

* Corresponding author: \#95/3, Adarsh Nagar, Dera Bassi, Dist. Mohali, Punjab-140507, India; e-mail: Sonia.4840@gmail.com

Received: 12 November 2020

Accepted: 7 July 2021

Published online: 11 November 2021

Acta Medica (Hradec Králové) 2021; 64(3): 174-182

https://doi.org/10.14712/18059694.2021.30

(c) 2021 The Authors. This is an open-access article distributed under the terms of the Creative Commons Attribution License (http://creativecommons.org/licenses/by/4.0), which permits unrestricted use, distribution, and reproduction in any medium, provided the original author and source are credited. 


\section{INTRODUCTION}

Enzinger and Harvey first reported on spindle cell lipoma (SCL) in 1975 (1), and this tumor is known to be a rare lipoma variant that represents about $1.5 \%$ of all adipocyte-origin tumors (2). Conventionally, depending upon the site, lipomas are classified into superficial, deep, and parosteal (3). Clinically they appear as non-tender, soft, mobile masses. Most of the time, the clinical detection of superficial lipomas is easy while the deep-seated or infiltrating lipomas may become difficult to diagnose and require further investigations such as imaging (4). Submandibular space is a very rare site of occurrence for SCL. We report a rare 5th case of SCL involving the submandibular space in an 18-year-old male patient with a concise review of the literature. A search of the online database yielded only four other case reports of SCL involving the submandibular space directly or indirectly till date (Table 1).

Tab. 1 Cases of Spindle cell lipoma in the submandibular space reported in the literature (1989-2020).

\begin{tabular}{|l|l|l|l|}
\hline S. no. & $\begin{array}{l}\text { Authors } \\
\text { (Year) }\end{array}$ & Age/sex & Location of tumour mass \\
\hline 1. & $\begin{array}{l}\text { Levy } \\
\text { et al. (1989) }\end{array}$ & $74 / \mathrm{F}$ & $\begin{array}{l}\text { The palpation of mass through } \\
\text { the submandibular triangle } \\
\text { was without any fixation to } \\
\text { the submandibular gland. }\end{array}$ \\
\hline 2. & $\begin{array}{l}\text { Braumann } \\
\text { et al. (2001) }\end{array}$ & $45 / \mathrm{M}$ & $\begin{array}{l}\text { Tender swelling of the right } \\
\text { parotid area reaching the } \\
\text { submandibular region. }\end{array}$ \\
\hline 3. & $\begin{array}{l}\text { Coimbra } \\
\text { et al. (2006) }\end{array}$ & $29 / \mathrm{F}$ & $\begin{array}{l}\text { Adjacent to the opening of the } \\
\text { Wharton duct. }\end{array}$ \\
\hline 4. & $\begin{array}{l}\text { Yalcin } \\
\text { et al, (2015) }\end{array}$ & $49 / \mathrm{F}$ & $\begin{array}{l}\text { Superficially located in front of } \\
\text { the sublingual caruncle. }\end{array}$ \\
\hline 5. & $\begin{array}{l}\text { Present } \\
\text { case***** }\end{array}$ & $18 / \mathrm{M}$ & Left submandibular region. \\
\hline
\end{tabular}

\section{CASE REPORT}

An 18-Year-old male patient reported with a painless swelling in the left submandibular region. He had been aware of the lesion for 3 months. He had difficulty in mastication without any associated pain. No history of trauma or inflammation of the area could be recalled. Patient was moderately built, with well orientation of the surroundings. All the vital signs were normal. He didn't reveal any relevant medical or habitual history.

Extraoral examination revealed a smooth surfaced, soft mass $(4 \mathrm{~cm} \times 5 \mathrm{~cm})$ with well-defined margins in the left submandibular region (Figure 1A). The swelling was more prominent with the teeth clenching and reduced in size on relaxation. On palpation, the swelling was slightly tender, soft, and fluctuant. It raised the floor of the mouth on applying pressure on it from outside. Computerized tomography (CT) Scan and Magnetic resonance imaging (MRI) were advised, but patient refused to go for any of these due to poor socioeconomic status. Ultrasonography (USG) of the lesion showed a hyperechoic mass in the region of left neck anterolateral to the left submandibular gland with well-defined margins and homogeneous texture. The mass did not show any evidence of calcification or vascularity. No lymphadenopathy was observed.

The clinical differential diagnosis made for submandibular region swelling included ranula/dermoid cyst or salivary gland tumor. The tumor mass was partially above the mylohyoid muscle and the bulk of it was below the mylohyoid muscle in the submandibular space (Figure 2). So, the superficial part of the lesion was excised along with the sublingual gland by intraoral sublingual approach, and the bulk of the tumor mass below the mylohyoid muscle was removed extra orally by the standard submandibular approach. The specimen (Figure 1B) in toto was sent for histopathological examination.

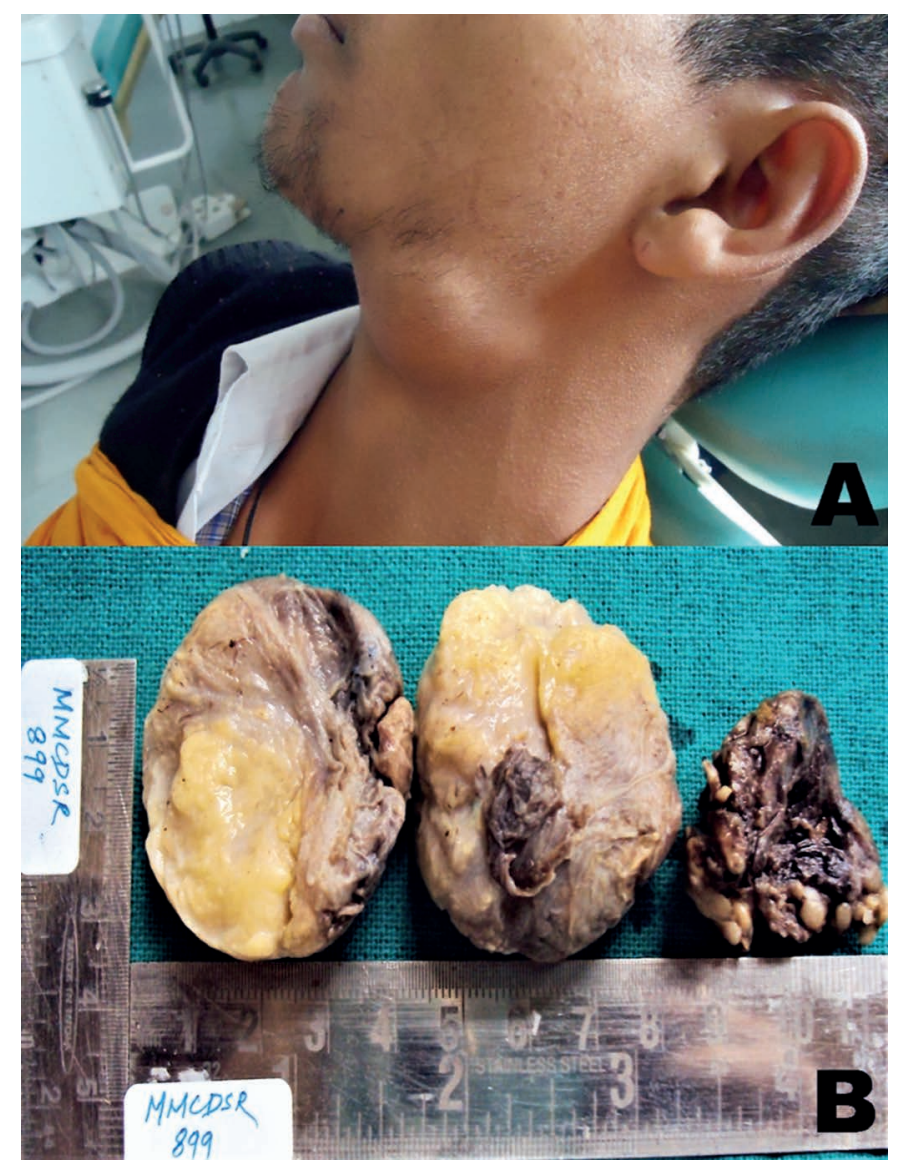

Fig. 1 A) Clinical photograph showing swelling in the left submandibular region. B) Photograph of gross excisional tissue.

On histopathological examination, H \& E stained sections revealed the presence of well -circumscribed tumor mass composed of lobules of normal mature adipocytes with clear cytoplasm and a peripheral nucleus giving a signet ring appearance. The lipocytes were separated by spindle cells and fibrous tissue (Figure 3A,B). Cellular areas were composed of spindle cells with elongated nuclei and scant cytoplasm along with bundles of dense ropey collagen fibers (Figure 4A,B). While excised sublingual gland revealed the presence of lobules of mucus acini separated by connective tissue septa. Based on these features, a histopathological diagnosis of SCL along with normal sublingual gland was given. Immunohistochemical (IHC) Staining with CD34 demonstrated strong intracytoplasmic 
reactivity in many spindle cells (Figure 5A,B), confirming the histopathological diagnosis of SCL (Figure 6). SCL being a benign lesion is treated with surgical excision only without need of any other therapy. And the recurrence rates have been reported very rare. In the present case also, surgical excision was done. Postoperative healing was uneventful and 4 years after surgery the patient was free of Postoperative healing was uneventful and 4years after surgery the patient was free of recurrence.

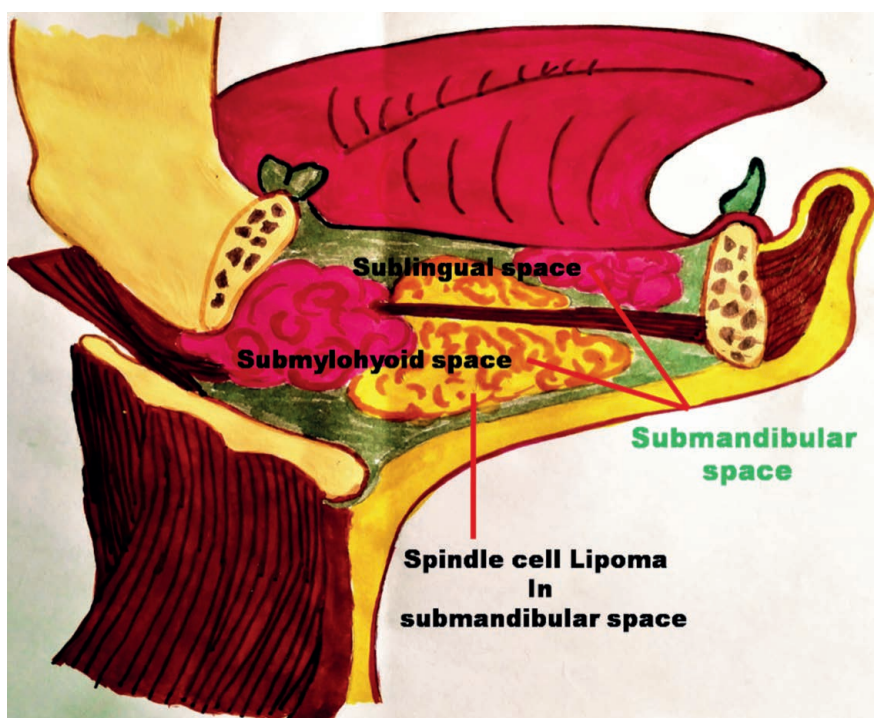

Fig. 2 Tumor mass occupying the submandibular space, partially above the mylohyoid muscle (sublingual space) and the bulk of it in the sub mylohyoid space.

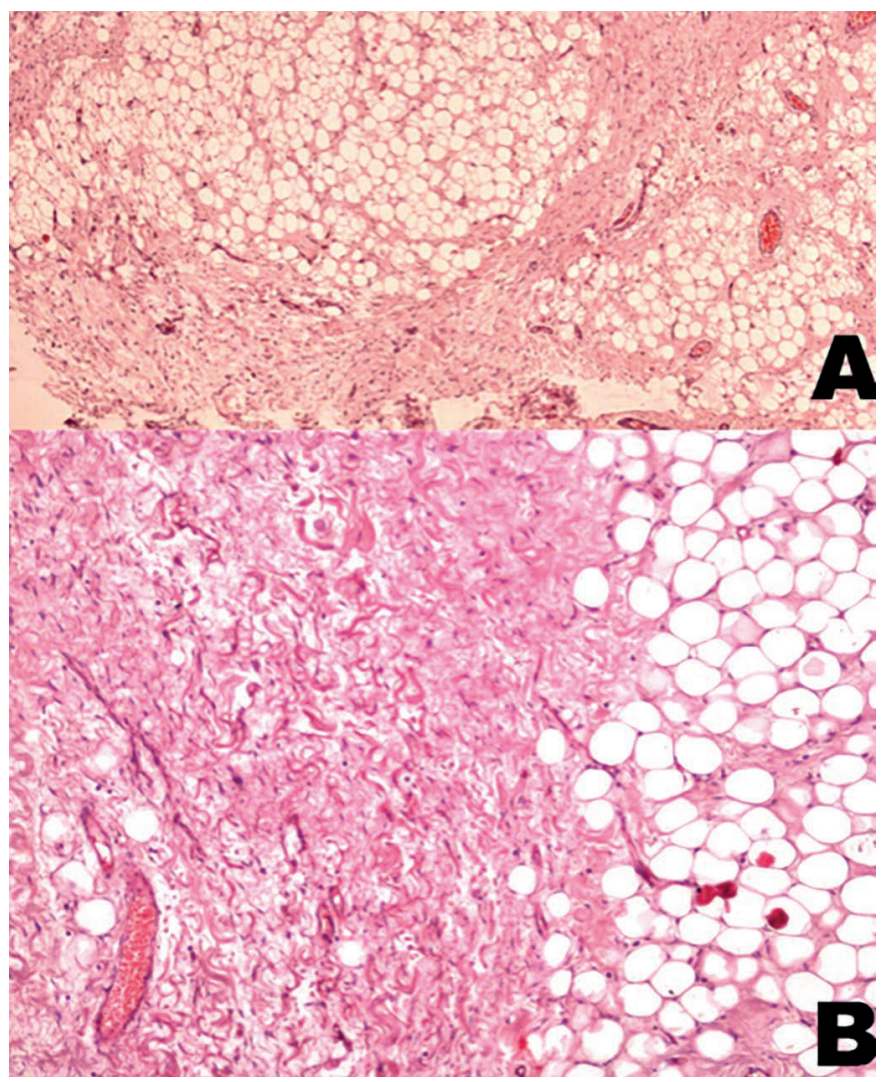

Fig. 3 A) Photomicrograph showing lobules of normal mature lipocytes separated by spindle cells and fibrous tissue (H\&E stain, $40 \times)$; B) (H\&E, 100x).

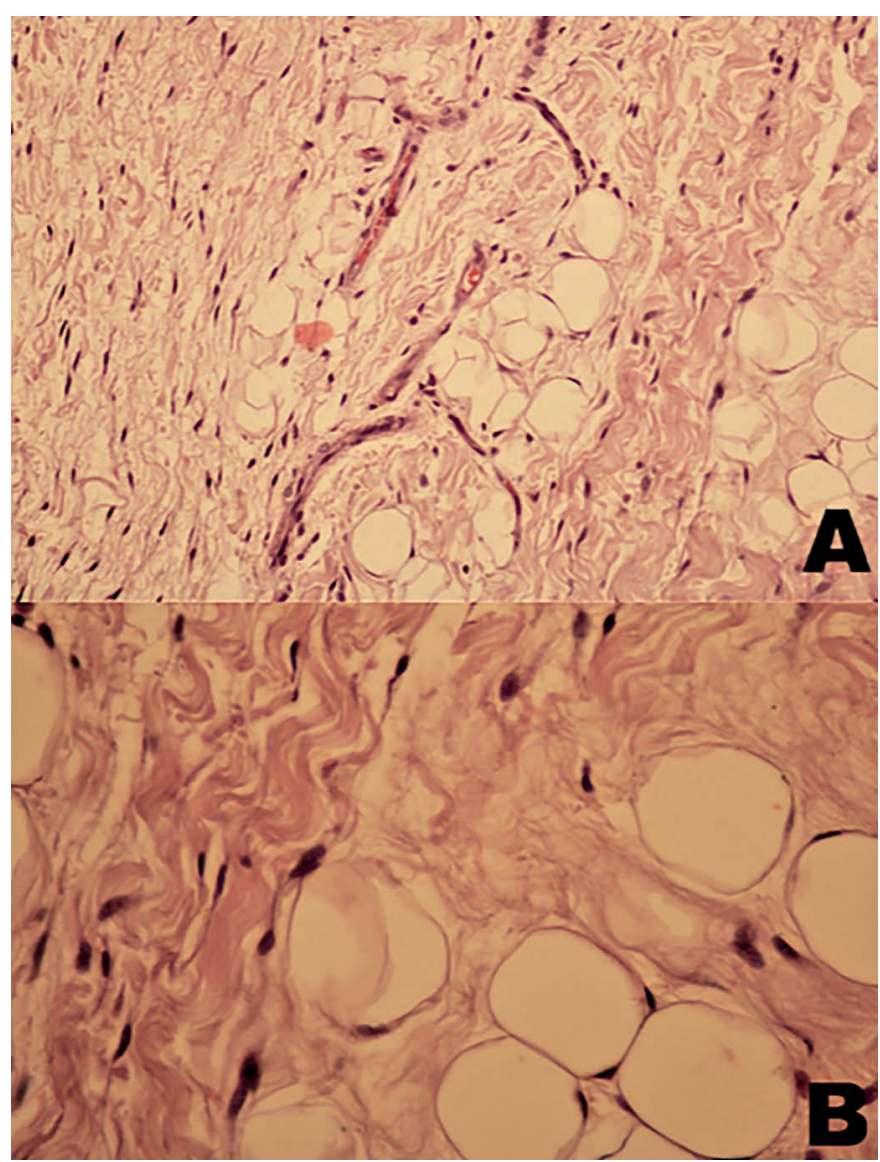

Fig. 4 A) Spindle cells with elongated nuclei and scant cytoplasm along with bundles of dense ropey collagen fibers along with mature adipocytes (H\&E stain, 200x); B) (H\&E stain, 400x).

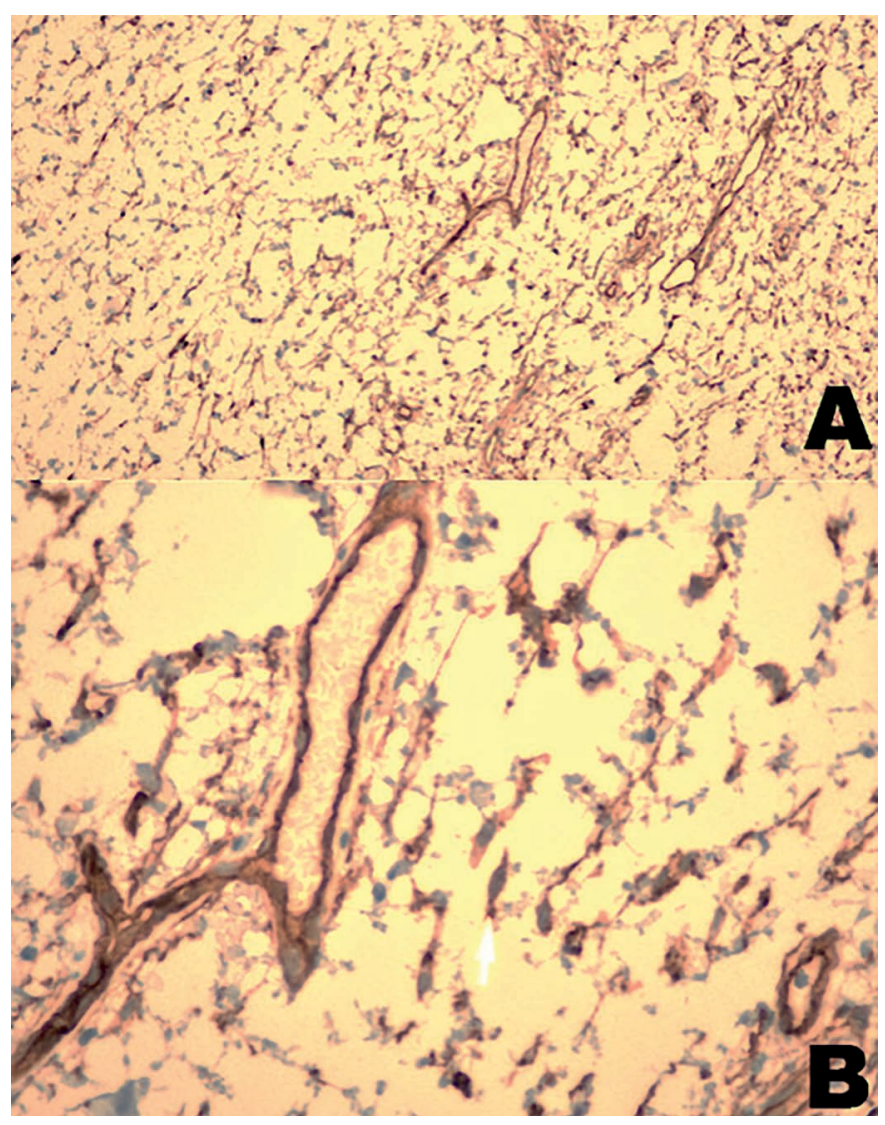

Fig. 5 A) Immunopositivity for CD34 by spindle cells (100x); B) $(400 \times)$. 


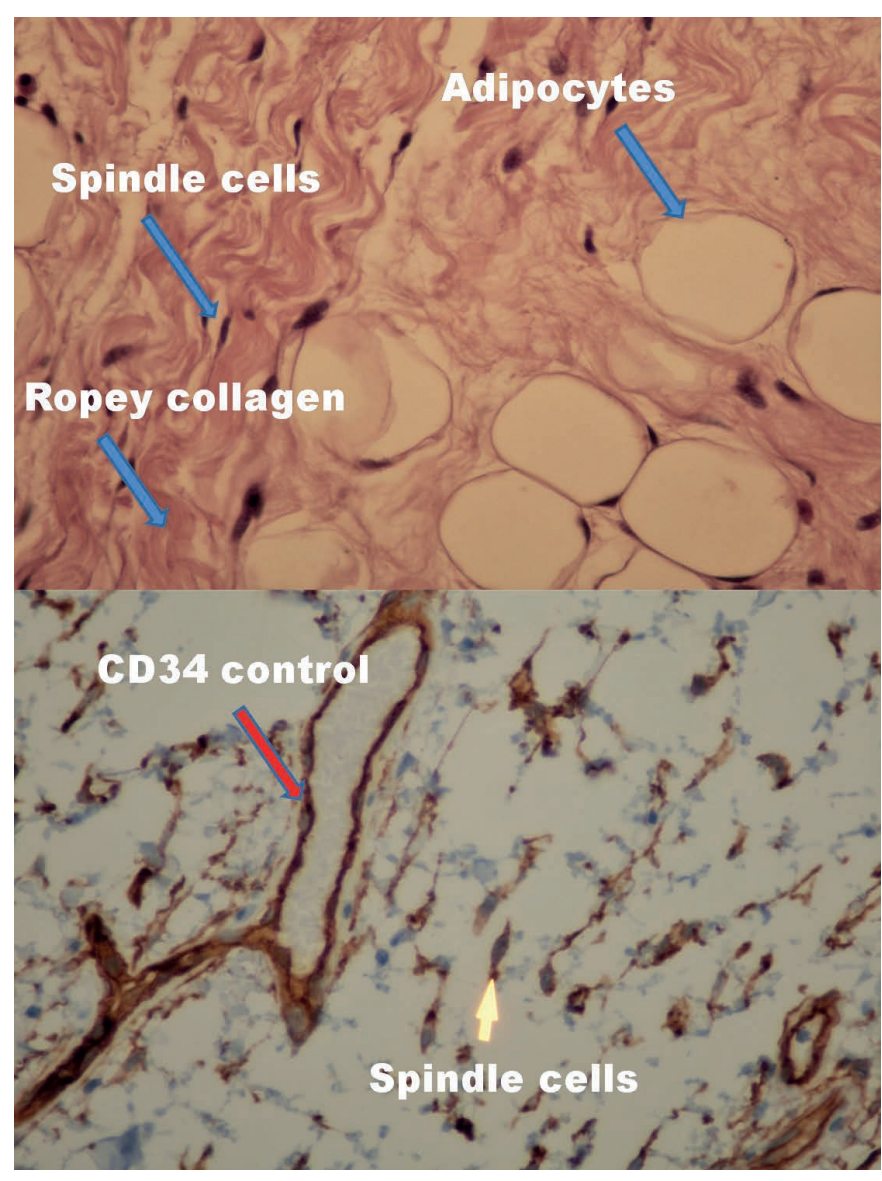

Fig. 6 Co-relation of CD34 immunopositivity with the histological $\mathrm{H} \& E$ staining slide confirming the final diagnosis of spindle cell lipoma.

\section{DISCUSSION}

Lipomas are the benign mesenchymal tumors occurring mostly in the subcutaneous tissues of the head and neck (5). These tumors are very rare in the oral region. Histologically, many variants of lipoma have been described based on the type of tissue present (6) (Table 2). SCL is a rare histological subtype of lipoma which was first described by Enzinger and Harvey in 1975 based on its characteristic histological findings (1).

\section{CLINICAL FEATURES}

SCL occurs mostly in the 4 th-6th decade with male predominance (male : female $=2: 1$ ) (7). Familial occurrence has also been reported (8). Most exclusively SCL involves subcutaneous tissue of the upper back, shoulders, and posterior neck (9). Intraoral SCL is very rare, and the main site of occurrence is buccal mucosa followed by tongue, gingiva, palate, alveolar ridge, and lip. This pattern corresponds closely to the quantity of fat deposits in the oral cavity. A few cases have been reported in parotid gland too (10-12). Submandibular space is a very rare site of involvement for SCL (13). In the literature only four cases of SCL involving the submandibular space directly or indirectly have been reported. Levy et al., in 1989, presented the first case of SCL in 74-year female patient occurring on the floor of mouth, in which palpation of mass through the submandibular triangle was noticed without any fixation to the submandibular gland (14). Baumann et al., in 2001 reported a case of SCL in a 45 -year-old male with a tender

Tab. 2 Histological variants of Lipoma.

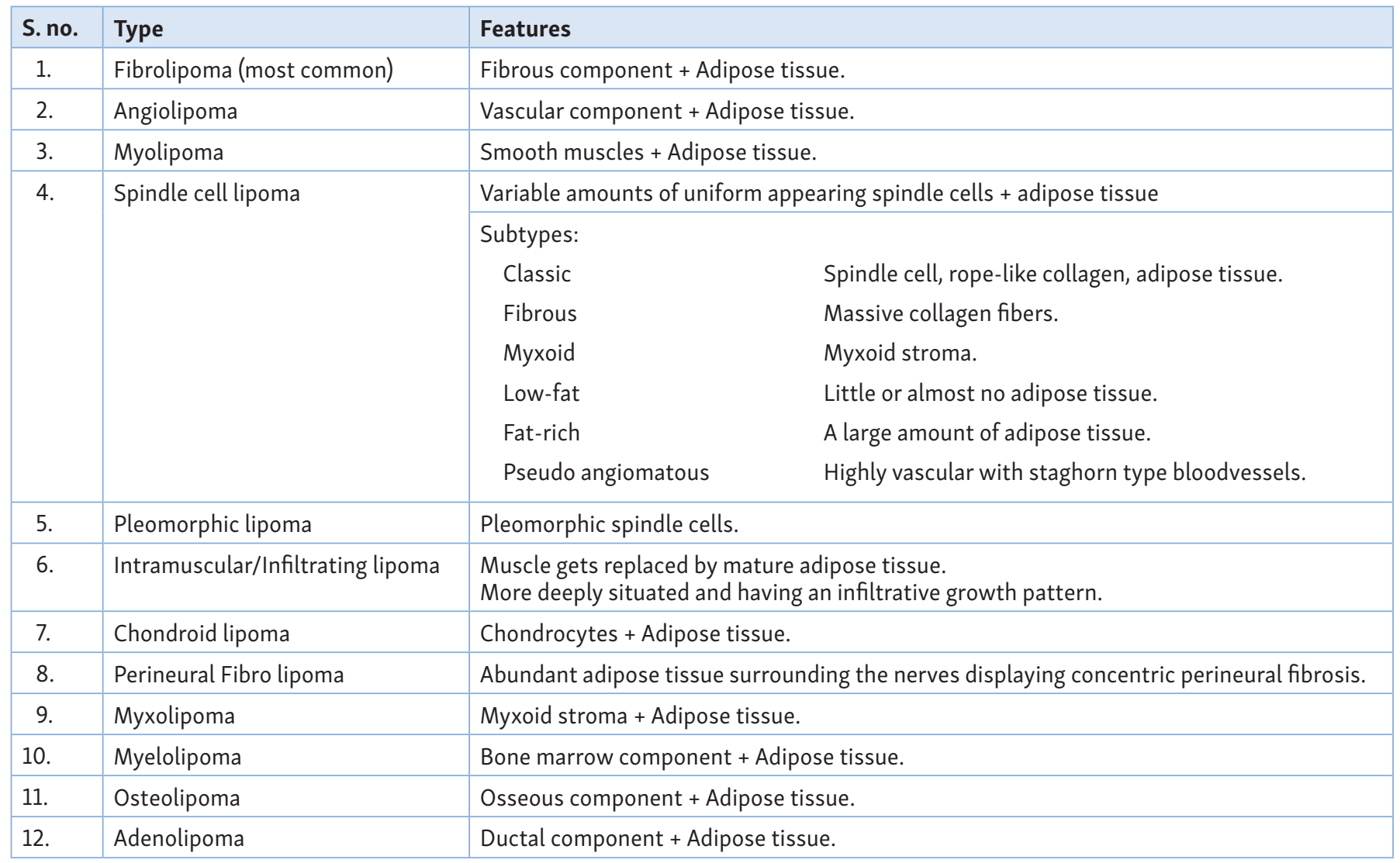


swelling of the right parotid area that had reached the submandibular region (15). Coimbra et al., in 2006 described a case of SCL in a $29 \mathrm{yr}$ female occurring on the floor of the mouth in which the lesion was located adjacent to the opening of the Wharton duct of the submandibular gland (16). Yalcin et al., in 2015 published a case of SCL in a 49-yr. old female in which the tumour was superficially located and non-infiltrating in front of the sublingual caruncle (opening of the submandibular and sublingual duct) on the floor of the mouth (17).

Though SCL involves mostly males, surprisingly the reported cases of SCL occurring in the submandibular region have revealed the female predominance (13-19). Out of 4 cases, only 1 occurred in a male. Our case is involving an 18-year male patient reflecting a rare feature of SCL in submandibular space. Clinically, intraoral SCL appears as a yellow coloured, soft, painless, well-circumscribed submucosal, slow growing mass of appx $1 \mathrm{~cm}$ in diameter. The size may extend up to $5-10 \mathrm{~cm}$ too (9). In our case, the lesion was soft, fluctuant, slightly tender, slow-growing, appx $5 \mathrm{~cm}$ in diameter with normal skin colour. The swelling raised the floor of the mouth on pressing from outside.

\section{CLINICAL DIFFERENTIAL DIAGNOSIS}

Lesions occurring in the submandibular space are of great clinical importance because this space has numerous tightly netted vital structures in contiguity with each other. The submandibular space extends from the hyoid bone to the mucosa of the floor of the mouth and is bounded anteriorly and laterally by the mandible, medially by the anterior belly of the digastric muscles, superiorly by the mylohyoid muscle. Space is enclosed by the superficial layer of the deep cervical fascia, except along the posterior margin of the mylohyoid muscle, permitting continuity with the sublingual space and potential communication with the parapharyngeal space through a buccopharyngeal gap created by the styloglossus muscle. Mylohyoid muscle plays a key role in determining the direction of the spread of tumor mass. The lesion that is in the sublingual space i.e. above the mylohyoid muscle has got the potential to grow into the sub mylohyoid space i.e. below the mylohyoid muscle, thus involving the whole of submandibular space (Figure 2) and presenting as a swelling in the neck (i.e. having both oral and cervical components). The primary contents include the superficial portion of the submandibular gland, submandibular lymph nodes, and fat. The facial artery and vein, as well as a portion of the hypoglossal nerve, course through space.

Pathologies occurring in the submandibular region are very challenging to diagnose because most of these entities manifest as swelling that can mimic many other lesions clinically (Table 3). The lesions in this region range from the most benign forms such as ranula to the sinister malignant neoplasms. Due to wide communications of this space, the actual extent and appearance of the lesions get masked up especially those occurring in deeper tissues leading to an inaccurate diagnosis (20). Various clinical differential diagnosis of lipoma occurring in submandibular region can be as follow:
1. Ranula: It represents as a mucocele that involves the sublingual glands. As the cystic lesion enlarges, it can rupture through its sublingual space boundaries extending into the submandibular space referred to as a plunging ranula and raises the floor of the mouth on putting pressure from outside. But ranula mostly occurs in the young age group of 1st to 2 nd decade with female predominance, while lipoma has different age predilection. Moreover, Ranula appears as a bluish swelling whereas lipoma is mostly yellowish (21).

2. Oral lymphoepithelial cysts: They appear as a movable yellow or yellowish white, painless submucosal nodule which is usually small as compared to those seen in lipoma. And these cysts usually occur in the first to third decade of life while lipoma occurs in 4 th to 6 th decades (22).

3. Dermoid \& Epidermoid cysts: These cysts are considered to be a variation of teratomas and arise from entrapment of epithelial remnants during the closure of the branchial arches or as a result of trauma. These appear as soft to rubbery swelling mainly located on the floor of the mouth superficially within submandibular and sublingual spaces either in midline or latterly, where they may cause tongue elevation, submental protrusion, or both (23) but they may also produce another mass in the neck from where they originally arose due to the sequestration of cutaneous tissue along cervical embryonic lines of closure, later extending to the mouth. These cysts mostly involve the young age groups whereas lipoma occurs mostly in the old age.

4. Benign salivary gland tumors: Any small lesion especially pleomorphic adenoma occurring in the submandibular region with slow growth, non-infiltration, without evidence of pain, induration, ulceration, and mucosal changes may be mistaken for lipoma but their other characteristic features help distinguishing them from lipoma which are described in table 3 (16).

5. Malignant salivary gland tumors: Some of the malignant salivary gland tumours involve the submandibular space such as Adenoid cystic carcinoma (AdCC), Mucoepidermoid carcinoma (MEC), Carcinoma-ex-PA, Acinar cell carcinoma, Mucinous adenocarcinoma, and Squamous cell carcinoma (24). But as compared to lipoma, they may be associated with other clinical features such as pain, ulceration, perineural invasion, more distant metastasis, high recurrence rate, worse prognosis, and different line of treatment.

6. Benign mesenchymal neoplasms: Lymphatic malformations such as lymphangioma occurring most commonly in the submandibular space may mimic lipoma. The characteristic appearance is a non-enhancing multiloculated cystic lesion with fluid-fluid levels without calcifications. Vascular tumours such as haemangioma occurring rarely in the submandibular space can also resemble sometimes to lipoma but it appears to be reddish or bluish, highly vascular and may produce blanching of tissue on compression and is mostly congenital (25). Schwannomas and neurofibromas are rare within the submandibular space. Arising from peripheral and sympathetic nerves, schwannomas involving the lingual and hypoglossal nerves can occur on the floor of the mouth and can resemble lipoma. 


\section{DIAGNOSTIC AIDS}

\section{ROLE OF IMAGING}

Imaging modalities such as CT, MRI, and USG are recommended in certain cases especially which extend from the neck to deeper tissues, to know the extent, location, and delimitation of the margins of the mass. Lipomas do not show characteristic pathognomic features on imaging (26). They may show a homogeneous appearance with the same density as subcutaneous fat in CT scan. On MRI these lesions may show a strikingly high-intensity signal, equal to that of the subcutaneous adipose tissue on both T1- and T2-weighted images (27). USG findings suggest hypoechoic masses in the majority of the cases with small echogenic lines. Some cases also reported lipomas as isoechoic masses (19). In the present case, USG was performed which revealed the presence of a hyperechoic mass in the region of left neck anterolateral to the left submandibular gland with clear well defined anterior and posterior margins. The mass did not show any evidence of calcification or vascularity. No lymphadenopathy was observed. Thyroid glands were normal.

Tab. 3 Clinical differential diagnosis of spindle cell lipoma occurring in submandibular space.

\begin{tabular}{|c|c|c|c|}
\hline Lesion & $\begin{array}{l}\text { Age } \\
\text { (decades) }\end{array}$ & Sex & Clinical features \\
\hline $\begin{array}{l}\text { Spindle cell } \\
\text { lipoma }\end{array}$ & 4th-6th & Females & $\begin{array}{l}\text { Yellow, soft, } \\
\text { painless, well- } \\
\text { circumscribed } \\
\text { submucosal slow- } \\
\text { growing mass of } \\
\text { appx } 1-5 \mathrm{~cm} \text { in } \\
\text { diameter. }\end{array}$ \\
\hline Ranula & 1st-2nd & Females & $\begin{array}{l}\text { Bluish grey, soft, } \\
\text { may raise the floor } \\
\text { of the mouth on } \\
\text { applying pressure. }\end{array}$ \\
\hline $\begin{array}{l}\text { Lymphoepithelial } \\
\text { cyst }\end{array}$ & 1 st-3rd & $\begin{array}{l}\text { Not } \\
\text { specific }\end{array}$ & $\begin{array}{l}\text { Soft submucosal } \\
\text { nodules, small in } \\
\text { size, yellow. }\end{array}$ \\
\hline $\begin{array}{l}\text { Dermoid/ } \\
\text { epidermoid cysts }\end{array}$ & $1 s t-3 r d$ & $\begin{array}{l}\text { Not } \\
\text { specific }\end{array}$ & $\begin{array}{l}\text { Soft rubbery } \\
\text { swellings, small } \\
\text { size, cause tongue } \\
\text { elevation, submental } \\
\text { protrusion. }\end{array}$ \\
\hline $\begin{array}{l}\text { Benign salivary } \\
\text { gland tumour }\end{array}$ & 3rd-5th & Females & $\begin{array}{l}\text { Soft painless } \\
\text { swelling of normal } \\
\text { skin colour, may } \\
\text { be associated with } \\
\text { facial nerve palsy. }\end{array}$ \\
\hline $\begin{array}{l}\text { Malignant } \\
\text { tumours }\end{array}$ & 2nd-9th & Females & $\begin{array}{l}\text { Painful swelling } \\
\text { associated with } \\
\text { ulceration, } \\
\text { perineural invasion, } \\
\text { distant metastasis, } \\
\text { poor prognosis. }\end{array}$ \\
\hline $\begin{array}{l}\text { Benign } \\
\text { mesenchymal } \\
\text { tumour }\end{array}$ & $3 r d-5$ th & Females & $\begin{array}{l}\text { Vary depending on } \\
\text { the tissue involved. } \\
\text { Soft to firm, } \\
\text { swelling may be } \\
\text { highly vascular, } \\
\text { multiloculated cystic } \\
\text { lesions. }\end{array}$ \\
\hline
\end{tabular}

\section{Histopathological investigations}

It is difficult to differentiate clinical lesions without histopathological investigations. To reach out at the accurate diagnosis, histopathological examination is essential. The lesions which are similar to spindle cell lipoma clinically, show different histological features that help to reach an accurate diagnosis (Table 3 ).

\section{Macroscopic features}

Grossly, SCL is well encapsulated and well-circumscribed appearing as classic lipoma with few differences. Cut surface may be nodular with grayish-white to grayish-yellow gelatinous foci representing the area of spindle cell formation (28). Due to the admixture of collagen fibers and the adipose tissue the surface texture may be soft to touch. No evidence of necrosis or vascularity has been reported (6). In the present case also the tumor mass was well encapsulated with cut surface showing yellowish nodular areas along with grayish-white gelatinous foci.

\section{Microscopic features}

Microscopically, SCL is composed of mature adipocytes along with mitotically inactive spindle cells associated with ropey collagen fibers surrounded by a clear fibrous capsule. Also, scattered mast cells, lymphocytes, multinucleated giant cells, and blood vessels are also observed. The spindle cells are characterized by pale staining vesicular, oval, or compressed nuclei, with a sparse, poorly defined, eosinophilic cytoplasm and, sometimes they demonstrate nuclear palisading (8). Spindle cells are bland, with uniform staining, without obvious atypia, pleomorphism, or nuclear mitoses, and are arranged in bundles between the collagen fibers (29). Sometimes infrequent variations can also be found in these classical features, giving rise to various other subtypes such as fibrous, myxoid, fat-rich, low-fat, and pseudo angiomatous types (30) (Table 2). In the present case, the H\&E stained section of the lesion represented classical histological features of SCL characterized by the presence of well-circumscribed tumor mass composed of lobules of normal adipose tissue separated by connective tissue septa and areas of loose myxoid matrix containing bland spindle-shaped cells along with the bundle of dense ropey collagen fibers. The cells had elongated nuclei and scant cytoplasm. Numerous thick-walled blood vessels and mast cells were also seen in the connective tissue stroma. Based on these features, a histopathological diagnosis of SCL was given.

The exact origin of spindle cells is not clear, but it has been reported to be fibroblastic in origin rather than lipoblastic (31). They may also be derived from adipocytic lineage or immature mesenchymal cells. Another possible origin from dendritic interstitial cells has also been mentioned (32). It is suggested that spindle cells are analogs to the nonlipoblastic stellate mesenchymal cells of the primitive fat lobules (33), which have lost their ability to differentiate to lipocytes but are capable of collage synthesis (34). The presence of mature lipocytes and fibroblastic cells in SCL probably reflects the potential to tumor cells to differentiate to both fat-storing and collagen-producing cells (35). 
Tab. 4 Histopathological differential diagnosis of spindle cell lipoma.

\begin{tabular}{|l|c|l|c|c|c|}
\hline Tumour & Adipocytes & Spindle cells & Ropey Collagen & Vascularity & Infiltration \\
\hline SCL & + & $\begin{array}{l}\text { Bland, uniform, } \\
\text { Isomorphic nuclei, } \\
\text { No pleomorphism and hyperchromasia, no } \\
\text { mitotic figures. }\end{array}$ & + & Not highly vascular. \\
\hline Classic lipoma & Localized. & - & - \\
\hline Fibro lipoma & Mature. & - & - & Not highly vascular. \\
\hline SFT & - & - & - & Not highly vascular. & - \\
\hline Neurofibroma & - & Wavy nuclei. & - & Highly vascular. & - \\
\hline Leiomyoma & - & Same as SCL. & - & Not highly vascular. \\
\hline Fibrosarcoma & - & $\begin{array}{l}\text { Arranged in fascicles, herringbone pattern, } \\
\text { pleomorphic, hyperchromatic, mitotic } \\
\text { figures. }\end{array}$ & - & Not highly vascular. \\
\hline WDL & - & Pleomorphic nuclei, hyperchromatic, mitosis. & - & Not highly vascular. & + \\
\hline Vascular tumours & - & - & - & Highly vascular. & + \\
\hline DFS & - & May resemble the fascicular type of SCL. & - & Not highly vascular. & + \\
\hline DFS: Dermatofibrosarcoma protuberans, SCL: Spindle cell lipoma, SFT: Solitary fibrous tumour, WDL: Well-differentiated liposarcoma. \\
\hline
\end{tabular}

\section{HISTOPATHOLOGICAL DIFFERENTIAL DIAGNOSIS}

Histopathologically, many features of SCL can resemble other lesions making it difficult to distinguish it from those entities. (Table 4) The following are the possible microscopic differential diagnosed lesions for SCL.

Classic lipoma: The spindle cells sometimes are so localized that they can be overlooked letting the tumour be diagnosed as an ordinary lipoma (9).

Fibro lipoma (FL): FL are characterized by an admixture of mature fat cells and fibrous connective tissue devoid of bundles of spindle cells and mast cells. Even IHC can't distinguish between SCL and FL because both tumors stain positive for vimentin and CD34 (36).

Solitary fibrous tumour (SFT): Spindle cells and collagen fibers in SCL and SFT seem to be similar, but the absence of adipocytes and the presence of abundant vascularity in SFT differentiates the two lesions. Ropey collagen fibers are the feature of SCL, not SFT. SCL is characterized by hypocellular stroma as compared to SFT which has hypercellular activity. Also, SFT occurs rarely in the oral cavity as compared to SCL (37).

Neurofibroma: Presence of spindle cells and mast cells may lead to a diagnosis of neurofibroma. But in neurofibroma, spindle cells have wavy nuclei and the lesions can be distinguished based on IHC investigations (38). Immunonegativity of spindle cells for S-100 helps to exclude the diagnosis of neurofibroma in which spindle cells are S-100 immunopositive.

Leiomyoma: Spindle cells of SCL \& Leiomyoma can resemble each other and both tumours being benign can result in difficulty to diagnose based on histological features (1).

Fibrosarcoma: Sometimes the spindle cells in SCL, are pleomorphic exhibiting hyperchromasia resembling fibrosarcoma like pattern (9).

Well-differentiated Liposarcoma (WDL) and Myxoid Liposarcoma (MLS): SCL with pseudolipoblastic change secondary to atrophy may mimic WDL/ atypical lipoma- tous tumor and myxoid liposarcoma $(39,40)$. In WDL, lipoblasts are rarely seen (41). The diagnostic lesional cell of well-differentiated liposarcoma is an atypical hyperchromatic tumor cell, typically without a cytoplasmic fat vacuole. These atypical hyperchromatic cells are often found in dense fibrous bands rather than the wiry ropy collagen of SCL. Also, pseudo lipoblasts are arranged in a lobular arrangement rather than the more random distribution seen in liposarcoma (41). WDL is immunonegative to CD34. Clinically, SCL is superficially located, well-circumscribed as compared to WDL which is deep seated and ill-defined (18). Myxoid Liposarcoma unlike SCL with myxoid stroma, typically shows prominent lipoblastic differentiation and have a characteristic "Chicken wire" vascular pattern rather than the wirey collagen characteristic of SCL. MLS is CD34 negative as compared to SCL which shows wide CD34 positivity (41).

Vascular tumours: Normally SCL is not vascular but the presence of high vascularity can mislead to the diagnosis of any vascular tumours (9).

Dermatofibrosarcoma protuberans (DFS): There is an overlap of histological features seen in DFS with SCL. The fascicular pattern of spindle cells may be seen in both the lesions. However, DFS is a cutaneous tumour exceptionally found in the oral region. And it also exhibits infiltrative nature as compared to SCL which is not infiltrative (42).

Due to the overlap of histological features of SCL with the above lesions, it becomes difficult to reach exact diagnosis. And that can be confirmed with help of IHC. The same was performed in our case too.

\section{IMMUNOHISTOCHEMICAL INVESTIGATIONS}

Immunohistochemical investigations can help resolving the conflicts of overlapping features of SCL with other lesions (Table 5). Studies have revealed that the spindle cells in SCL show intense immunopositivity for CD34, vimentin \& bcl-2 and immunonegativity for Alpha-smooth mus- 
Tab. 5 Immunohistochemical markers for differentiating various lesions from spindle cell lipoma.

\begin{tabular}{|c|c|c|c|c|c|c|c|c|}
\hline S.no & Name of lesion & CD 34 & $\mathrm{Bcl} 2$ & F-VIII & S-100 & CD-99 & Alpha SMA & Ki67 \\
\hline 1. & Spindle cell lipoma & + & + & - & - & - & - & - \\
\hline 2. & Solitary fibrous tumour & + & + & - & - & $-1+$ & - & - \\
\hline 3. & Neurofibroma & - & - & - & + & - & - & - \\
\hline 4. & Leiomyoma & - & - & - & - & - & + & - \\
\hline 5. & Liposarcoma & - & - & - & - & - & - & + \\
\hline 6. & Dermatofibrosarcoma protuberans & + & - & - & - & - & - & - \\
\hline
\end{tabular}

cle actin (SMA), Factor VIII, Cytokeratin (CK), and S-100 which eliminates the evidence of the muscular, neurogenic or endothelial origin of spindle cells found in SCL and helps to distinguish it from other neural, muscular and vascular tumours $(35,43)$. Ki67 expression is found to be very low in SCL which helps to distinguish it from malignant neoplasm like Liposarcoma in which tumour cells show a high proliferative index of Ki67 (44). In the present case, spindle cells showed immunopositive reaction with $\mathrm{CD} 34$ that is consistent with the findings reported in the literature.

\section{MANAGEMENT \& PROGNOSIS}

SCLs are mostly treated by surgical excision. These are benign lesions with a good prognosis. Recurrences are rare and are encountered only when the lesion is infiltrating and invading the surrounding muscles and tissues. However, surgical manipulation of spindle cell lipoma in the submandibular region must be cautioned as the lesion may be contiguous with vital structures such as the salivary glands and their respective ducts along with nerves and vessels mainly lingual nerves and vessels, hypoglossal nerves, and glossopharyngeal nerve. Malignant transformation is thought to be almost non-existent with very few cases reported. Long term follow up is necessary $(45,46)$. In the present case surgical excision was done and good post-operative healing was observed after 4 years of follow up with no recurrence.

\section{CONCLUSION}

Intraoral lipomas are rare as compared to other lipomas. SCL is a histological variant of lipoma that infrequently occurs in the submandibular region. Due to wide communications of submandibular space, the actual extent and appearance of the lesions present here get masked up especially those occurring in deeper tissues leading to an inaccurate diagnosis. Also, the slow expansile growth of lipoma probably allows neighboring structures to adapt to the increasing pressure, thus leaving the patient unaware of the growth. The wide overlap of clinical and histopathological features of SCL leads to a challenging task for the clinicians to reach an accurate diagnosis. Thorough investigations and evaluations are mandatory to frame out a proper diagnosis for providing preferential treatment to avoid further complications.
REFERENCES

1. Enzinger FM, Harvey DA. Spindle cell lipoma. Cancer 1975; 36: 1852-9.

2. Fletcher CD, Martin-bates E. Spindle cell: a clinicopathological study with some original Histopathology 1987; 11: 803-17.

3. Pusiol T, Franceschetti I, Scialpi M, Piscioli I. Oncocytic sialolipoma of the submandibular gland with sebaceous differentiation: A new pathological entity. Indian J Pathol Microbiol 2009; 52: 379-82.

4. El-Monem MH, Gaafar AH, Magdy EA. Lipomas of the head and neck. Presentation variability and diagnostic work up. J Laryngol Otol 2006; 120: 47-55

5. Miloro M, Haupt A, Olsson AB, Kolokythas A. Oral spindle cell lipoma: a rare occurrence and review of the literature. Oral Maxillofac Surg Cases 2015: 12-14.

6. Shafer WG, Hine MK, Levy BM. Shafer's textbook of oral pathology .6th ed. Elsevier publications: Noida, India 2009, p. 138.

7. Milhan NVM, Cavalcante ASR, Marques YMFS, Carvalho YR, Anbinder AL. Spindle cell lipoma occurring in the buccal mucosa: an unusual location of this benign lipomatous neoplasm. Case Reports Pathol 2015: 805730.

8. Kempson RL, Fletcher CDM, Evans HL, Hendrickson MR, Sibley RK. Tumors of the soft tissues Atlas of tumor pathology. Bethesda: Third Series Armed Forces Institute of Pathology, 2001, p. 203-8.

9. Piatteli A, Perrotti V, Fioroni M. Spindle cell lipoma of the floor of the mouth: report of a case. Auris Nasus Larynx 2005; 32: 205-7.

10. Amore FF, Musumeci G, Castrogiovanni P, Longo FR, Magro G. Spindle cell lipoma of peri-parotid soft tissues. Report of a case and histogenetic considerations. J Histol Histopathol 2015; 2: 7.

11. Fasig JH, Robinson RA, McCulloch TM, Fletcher MS, Miller CK. Spindle cell lipoma of the parotid: fine-needle aspiration and histologic findings. Arch Pathol Lab Med 2001; 125: 820-1.

12. Rosenthal LS, Garzon S, Setty S, Yao M. Left-sided facial mass. Spindle cell lipoma of the parotid gland. Arch Pathol Lab Med 2006; 130: 875-6.

13. McDaniel RK, Newland JR, Chiles DG. Intraoral spindle cell lipoma: case report with correlated light and electron microscopy. Oral Surg Oral Med Oral Pathol 1984; 57: 52-7.

14. Levy FE, Goding Jr GS. Spindle cell lipoma: an unusual oral presentation. Otolaryngol Head Neck Surg 1989; 101: 601-3.

15. Baumann I, Dammann F, Horny HP, Plinkert PK. Spindle cell lipoma of the parapharyngeal space. First report of a case. Ear, Nose, \& Throat Journal 2001; 80(4): 247-50.

16. Coimbra F, Lopes JM, Figueiral H, Scully C. Spindle cell lipoma of the floor of the mouth. A case report. Med Oral Patol Oral Cir Bucal 2006; 11: 401-3.

17. Yalçin M, Atilgan SS, Laçin N, Atalay Y. Spindle Cell Lipoma on the Floor of the Mouth. J Dent App 2015; 2(8): 291-4.

18. Billings SD, Henley JD, Summerlin DJ, Vakili S, Tomich CE. Spindle cell lipoma of the oral cavity. Am J Dermatopathol 2006; 28: 28-31.

19. Malthiery E, Costes-Martineau V, Fauroux MA, Torres JH. A $37 \mathrm{~mm}$ Spindle Cell Lipoma on the Floor of the Mouth. Case Reports in Dentistry 2019: 2138928.

20. Tan MS, Singh B. Difficulties in diagnosing lesions in the floor of the mouth - Report of Two Rare Cases. Ann Acad Med Singapore 2004; 33(Suppl): 72S-76S

21. Kokong D, Iduh A, Chukwu I, Mugu J, Nuhu S, Augustine S. Ranula: Current Concept of Pathophysiologic Basis and Surgical Management Options. World J Surg 2017; 41: 1476-81.

22. Joshi B, Rajesh G, Shivani B. Oral Lipoma-a Rare Clinical AnomalyA Case Report. Acta Scient Dent Sci 2018; 2(7): 114-7.

23. Sabhalok SS, Shetty LS, Sarve PH, Setiya SV, Bharadwaj SR. Epidermoid and dermoid cysts of the head and neck region. PlastAesthet Res 2016; 3: 347-50. 
24. Kessler AT, Bhatt AA. Review of the Major and Minor Salivary Glands, Part 2: Neoplasms and Tumor-like Lesions. J Clin Imaging Sci 2018; 8: 48 .

25. Egido-Moreno S, Lozano-Porras AB, Mishra S, Allegue-Allegue M, Marí-Roig A, López-López J. Intraoral lipomas: Review of literature and report of two clinical cases. J Clin Exp Dent 2016; 8(5): e597-e603.

26. Lee HK, Hwang SB, Chung GH, Hong KH, Jang KY. Retropharyngeal Spindle Cell/Pleomorphic Lipoma. Korean J Radiol 2013; 14(3): 493-6.

27. Upadhyay S, Sharma A, Mhashal S, Dabholkar JP. Spindle cell lipoma of the anterior triangle of the neck: a rare entity. Braz J Otorhinolaryngol 2011;77(3): 401 .

28. Darling M, Thompson I, Schneider J. Spindle cell lipoma of the alveolar mucosa: a case report. Oral Surg Oral Med Oral Pathol Oral Radiol Endod 2002; 93: 171-3.

29. Said-Al-Naief N, Zahurulla FR, Sciubba JJ. Oral spindle cell lipoma. Ann Diagn Pathol 2001; 5: 207-15.

30. Chen S, Huang H, He S, et al. Spindle cell lipoma: clinicopathologic characterization of 40 cases. Int J Clin Exp Pathol 2019; 12(7): 2613-21.

31. Miettinen MM, Mandahl N. Spindle cell lipoma/pleomorphic lipoma. In: Fletcher CDM, Unni KK, Mertens F, editors. Pathology and genetics of tumours of soft tissue and bone. Lyon: World Health Classification of Tumours International Agency for Research of Cancer (IARC) IARC Press; 2002: 31-2.

32. Horiuchi K, Yabe H, Nishimoto K, Nakamura N, Toyama Y. Intramuscular spindle cell lipoma: case report and review of the literature. Pathology Int 2001; 51: 301-4.

33. Bole JW, Thorning D. Spindle-cell lipoma. A clinical, light-and electron-microscopical study. Am J Surg Pathol 1981; 5: 435-41.

34. BehanA, Schmid C, Hodl S, Fletcher CDM. Spindle cell and pleomorphic lipoma:an immunohistochemical study and histogenetic analysis. J Pathol 1989; 157: 219-22.

35. Lombardi T, Odell Ew. Spindle cell Lipoma of the oral cavity: report of a case. J Oral Pathol Med 1994; 23: 237-9.
36. Templeton SF, Solomon AR Jr. Spindle cell lipoma is strongly CD34 positive. An immunohistochemical study. J CutanPathol 1996; 23: 546.

37. Wood L, Fountaine TJ, Rosamilia L, et al: Cutaneous CD34+ spindle cell neo- plasms: histopathologic features distinguish spindle cell lipoma, solitary fibrous tumor, and dermatofibrosarcoma protuberans. Am J Dermatopathol 2010; 32(8): 764-8.

38. Bajpai M, Pardhe N, Kumar M. Immunohistochemical differentiation between spindle cell lipoma and neurofibroma of oral cavity using CD34 and SOX10. Indian J Pathol Microbiol 2018; 61: 561-3.

39. Dominguez FV, Guglielmotti MB, Flores MC. Myxoid liposarcoma of the cheek. J Oral Maxillofac Surg 1990; 48: 395-7.

40. Nascimento AF, Mc Menamin ME, Fletcher CD. Liposarcomas/atypical lipomatous tumors of the oral cavity: a clinicopathologic study of 23 cases. Ann Diagn Pathol 2002; 6: 83-93.

41. Weiss SW, Goldblum JR. Enzinger and Weiss's soft Tissue Tumors. St. Louis: Mosby; 2001.

42. Jaeger F, Capistrano HM, de Castro WH, et al. Oral spindle cell lipoma in a rare location: a differential diagnosis. Am J Case Rep 2015; 16: 844-8.

43. Manor E, Sion-Vardy N, Brennan PA. Spindle cell lipoma of the oral cavity: a clinicopathologic analysis of 35 reported cases. Surgical Science 2013; 4: 196-201.

44. Linares MF, Leonel ACLS, Carvalho EJA, de Castro JFL, de Almeida OP, Perez DEC. Intraoral lipomas: A clinicopathological study of 43 cases, including four cases of spindle cell/pleomorphic subtype. Med Oral Patol Oral Cir Bucal 2019; 24(3): e373-8.

45. Manor E, Sion-Vardy N, Josua BZ, Bodner L. Oral lipoma: analysis of 58 new cases and review of the literature. Ann Diagn Pathol 2011; 15: 257-61.

46. Julliasse LE, Nonaka CF, Pinto LP, Freitas Rde A, Miguel MC. Lipomas of the oral cavity: clinical and histopathologic study of 41 cases in a Brazilian population. Eur Arch Otorhinolaryngol 2010; 267: 459-65. 